\title{
Case Study On Use Area Parking At New Market City Shopping Center Bogor
}

\author{
Syaiful $^{1}$, Yena Elvira ${ }^{2}$ \\ ${ }^{1}$ Department of Civil Engineering Faculty of Engineering, University of lbn Khaldun Bogor, \\ Student of Doctoral Program of PSL Bogor Agricultural University and BUDI-DN LPDP \\ Scholarship Recipient 2016 \\ ${ }^{2}$ Department of Civil Engineering Faculty of Engineering, University of Ibn Khaldun Bogor
}

e-mail: syaiful@ft.uika-bogor.ac.id

\begin{abstract}
New Market City Shopping Bogor is a research object to the availability of parking areas. Perception assessment of park users to park a distance of $42.86 \%$ with a distance of $200 \mathrm{~m}$, the distance is very great influence in determining the parking area. Difficulty entering the parking structure also affects the level of parking services at $39.52 \%$. Level of difficulty occurs because the road to the parking lot filled with public transportation that stops in the place.
\end{abstract}

Keywords: Perception, distance parking, parking service level.

\section{INTRODUCTION}

\subsection{Background}

New Market Shopping Bogor provides a large parking area. The area of the park in $3.080 \mathrm{~m} 2$ building, but the parking area is not utilized by park users. New Market Bogor parking space located above the building, along the temple and the frame on the right of way to force the vehicle to the parking lot. Determining the parking area and parking needs must first be assessed capacity and existing parking spaces. The need for parking is very different when compared to the open area and is affected by the designation.

\subsection{Problem Formulation}

Formulation of the problem is how the user's perception of the research park in New Market Bogor and what factors led to the ineffectiveness of parking spaces.

\subsection{Research Objectives}

The research objective was to obtain user perceptions of New Market parking Bogor and obtain the factors that cause ineffectiveness of parking spaces.

\subsection{Benefits of Re search}

Benefits of the research was to provide parking effective spacesNew Market Bogor and can provide input on the use of parking spaces.

\section{LITERATURE REVIEW}

\subsection{Definition of Parking}

The ride was using the vehicle begins and ends in the parking lot, so parking spaces scattered at the origin of the trip, could be in the parking deck, in the parking lot or on the side of the road. Parking is a vehicle stops in the long term and short situation and needs [6]. 


\subsection{Type of vehicle parking}

Types of vehicles using the parking facilities [1].

1) Motor vehicles, namely:

(1) Personal vehicles

(2) Public transportation

2) Non-motorized vehicles

(1) Personal vehicles such as bicycles

(2) Public transportation

\subsection{Position park}

The position of vehicles in parking spaces that blend or a part of the building or buildings intended, but it pendestrianpun must be considered, as the visitors walked away the place of destination, then the level of service for pedestrians must also be considered such as pavement, bridge crossing, zebracross, and others [5].

Parking outside the agency applied in places that pull big way so the smooth flow of traffic and environmental sustainability is maintained. Thus design-street parking outside the very need to align with the needs of parking spaces [1].

\subsection{Standard Parking Requirements}

Standard parking activity area needs differ from each other, depends on se veral things, among other services, the rates in force, availability of parking spaces, vehicle ownership levels, income levels. Based on the results of a study of the Directorate General of Land Transport [1].

Studies conducted by the Directorate General of Land Transport in 1998 on the activities and standards of parking requirements are as follows [5].

\subsection{Parking Facilities}

Parking facility is a public service facilities is an important factor in the transport system in urban areas. This argument shows that parking is a common service facilities and is an important part of the transport system, the transport system is a public utility while the quality of public infrastructure is a measure of the success of a society, thus it can be concluded that the successful management of parking in the market town of Bogor is a reflection of society's success Bogor city and vice versa, if the management of the park in the town of Bogor market does not work, then this is a reflection of the failure of the city of Bogor [3]. The existing parking area in the mall Ciputra and electronic shopping center Courts affect the characteristics of the road, and number of vehicles passing certain roads 8,9$]$.

\subsection{Various kinds of parking facilities}

Various kinds of vehicle parking facilities in urban principles to do on the road and off the road with its specific requirements [1].

1) On-street parking facilities are basic concepts related to the function of the parker. What's stopping and parking on the road should not be allowed, the amount of access to arterial roads is restricted to a minimum.

2) Parking facilities outside the road providing parking facilities outside the body can be, yard / garden parking lot is off-street parking facilities in the simplest. Generally parking is equipped with a parking meter and operated jointly with parking on the roadside. The appearance of the parking lot facing the street should be considered carefully. Usually done what the court is making pavement walking distance from the parking lot so that it can be limited by other crops

3) The parking deck site aspect considerations, related to the ease and convenience of park users to reach the parking facilities and parking facilities leading to Destination otherwise. The ease and 
comfort may be associated with a range of potential users walk from parking facilities. Distance range is unbelievably varied.

Parking studied included into the type of parking in the parking structure.

\subsection{Parking Regulations}

Regulation parking management depends on increasing vehicle ownership and vehicle volume will increase the demand for parking space requirements, to meet the needs of the specific areas to provide public parking facilities. According to the type of facility parking ordinance is as follows [4].

1) Parking facilities without control parking

2) Parking facility with parking control. Parking facility with parking control (use the entrance/exit).

\subsection{Regulation and Control of Parking Policy}

Regulation of parking policy is implemented parking restrictions on activity. Parking restrictions in the street or on the street outside the park that is applied primarily on the main streets and town centers. This policy is very effective to improve the road network services, in general, the closer the direction of movement towards the city center, the more obstacles encountered when driving a vehicle. By contrast, the movement toward the direction out of the city center, which is further away from the center to close anyway obstacles encountered $[1,10]$.

Table 1. Policy instruments in the field of parking shown

\begin{tabular}{|c|c|c|c|}
\hline No & Wisdom & On the side of the road & Off-street \\
\hline 1 & $\begin{array}{l}\text { Wisdom } \\
\text { rate }\end{array}$ & $\begin{array}{l}\text { 1. Increased tariffs, } \\
\text { 2. Users parking meters, } \\
\text { 3. Permission for use. }\end{array}$ & $\begin{array}{l}\text { 1. Tax the provision of parking } \\
\text { spaces, } \\
\text { 2. Interest rate structure to meet } \\
\text { the long for parking. }\end{array}$ \\
\hline 2 & Wisdom & $\begin{array}{l}\text { 1 Prohibit parking, } \\
2 \text { Prohibit parking with the } \\
\text { exception of the occupants, } \\
3 \text { Relocation of the parking lot. }\end{array}$ & $\begin{array}{l}\text { 1. Freeze the construction of a new } \\
\text { parking lot, } \\
\text { 2. Reduce existing parking } \\
\text { spaces, } \\
\text { 3. Controlling parking in the } \\
\text { future, } \\
\text { 4. Variations in load time } \\
\text { parking space. }\end{array}$ \\
\hline
\end{tabular}

\subsection{Parked vehicle control}

Controls on vehicles parked on the street in particular usually by location and time, but this requires strict enforcement and prosecution. The main control and commonly performed as follows [2].

1) Gauges parking (parking meter)

2) Card system and disk

3) Ticket system

\subsection{Unit Calculation of Parking Spaces (SRP)}

Unit Calculation of Parking Spaces (SRP) is to determine the required parking facilities and information about the dimensions of the vehicle from the driver's behavior (maneuver forward or backward) associated with SRP layout that includes angle parking, the width of the space (stall), wide aisle (aisle), and the direction of circulation vehicle. Vehicle dimensions variable influence in the layout of parking spaces can be shown in Figure $1[1,7]$. 

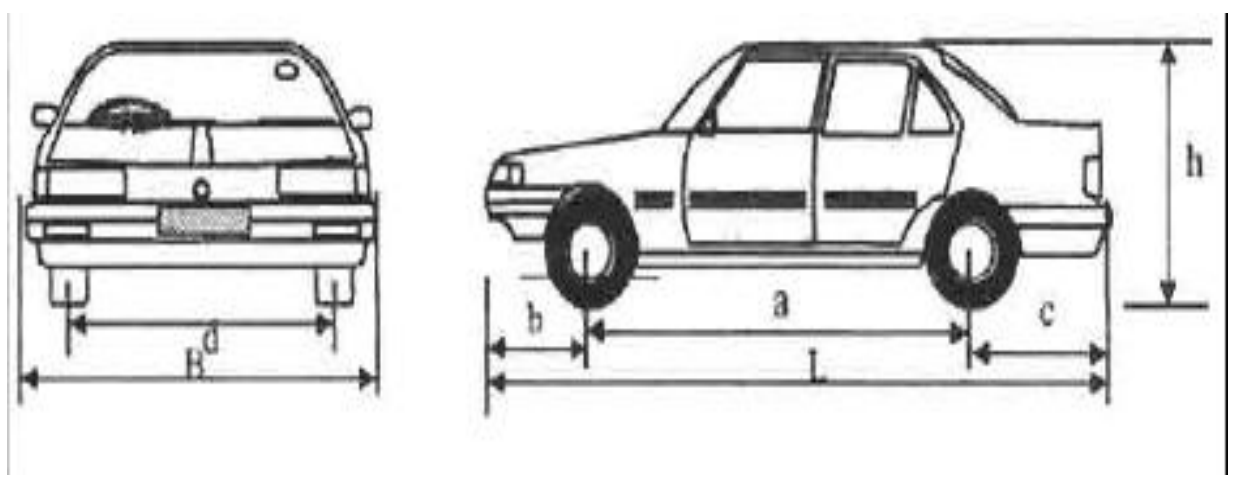

Figure 1. Dimensionalstructure ofpassengervehicles

\section{Caption :}

A =axlespacing,

$b=$ future depends(fron overhang),

$\mathrm{c}=$ reardependent(rearoverthang),

$\mathrm{h}=$ height,

$B=$ totalwidth,

$\mathrm{L}=$ total length.

\subsection{WillingnesstoPay (WTP)}

WTPis theavailability ofparkingusersto issuebenefitsor servicesreceived. The approach usedin the analysis ofWTPare basedon theuser'spreferences andperceptionsof theratesofgoodsor services. Transportation problems, WTPis influencedby several factors [4].

1) Quality andquantity

2) Utilitiesforthese services

3) Incomeuser

\subsection{Determination ofthe location of parking}

Determination oflocationsfor publicparking facilitiesbyministers. determination ofthe locationandconstruction of facilitiesfor thepublic, performedby observing [5].

1) General planlayout,

2) Safetyandsmooth traffic,

3) Environmental sustainability,

4) Convenience forservice users,

\subsection{PatternDeterminationParking}

Determinationofthe patternrefers to theparking lot, there are three kinds ofparkingpatterns, ieparallel $\left(0^{\circ}\right.$ angle), angle $\left(30^{\circ}, 45^{\circ}, 60^{\circ}, 75^{\circ}\right)$, and perpendicular(right-angle or $\left.90^{\circ}\right)$. Perpendicularparking isthe mostefficient in terms ofland useareavailable, but must beavailablea wideraisleso thatthe driver does notrun into trouble duringparkingmaneuvers [7].

\section{3.. WORKING PROCEDURE}

\subsection{Time andPlace/Location ofexistingre search site}

Whendoingresearchfor 30 days. The research siteisatNo. 3JalanSuryaKencana4th floorBogor. 


\subsection{The use of research equipment}

The use of equipment in the research used in the study use the parking spaces including the New Markets Bogor, questionnaire forms, stationery and cameras.

\subsection{Flowchart of research methods / user perceptions parking}

The method applied in the user's perception of park users park is shown below at Figure 2.

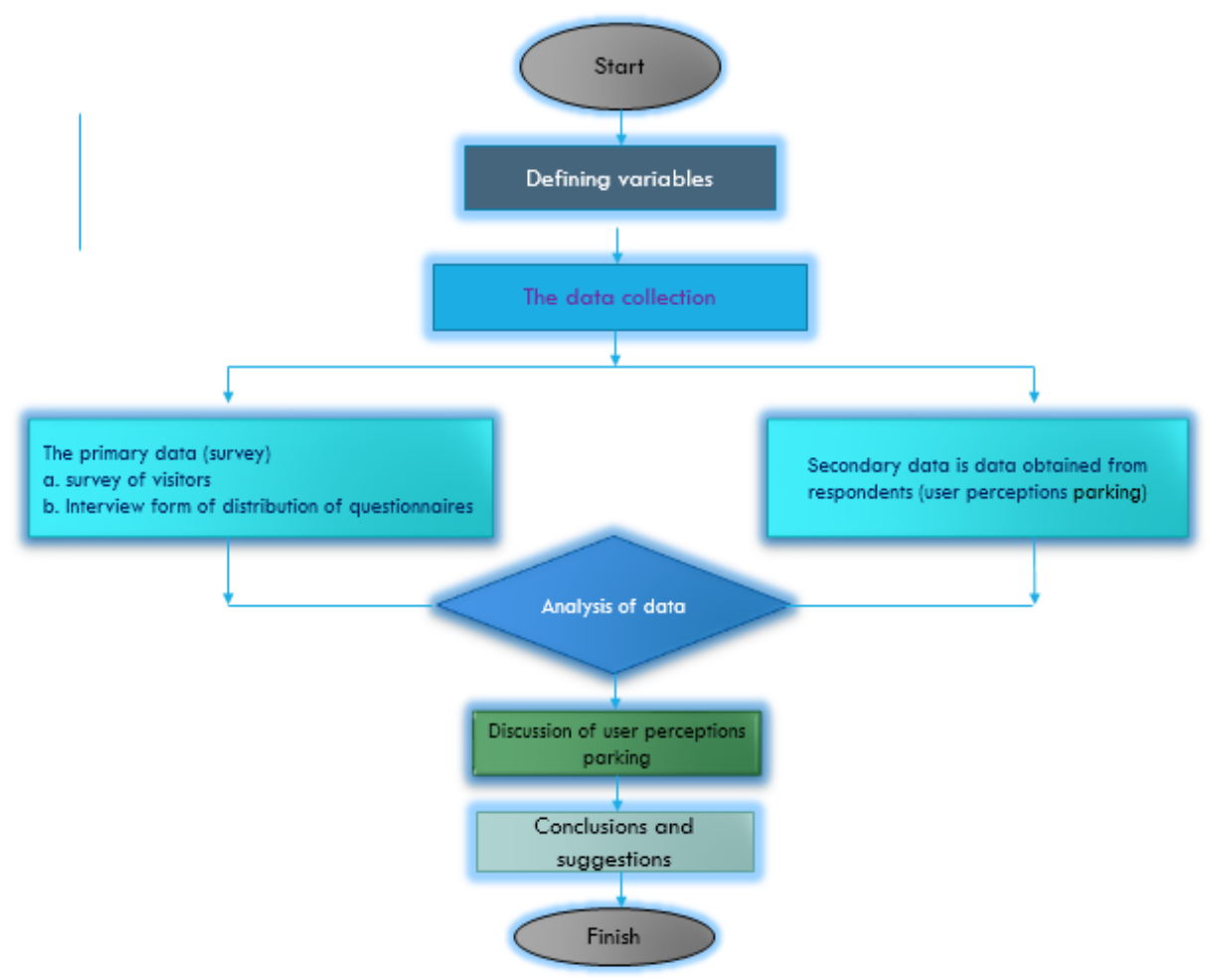

Figure 2. Flowchart of research methods

\section{RESULTS AND DISCUSSION}

\subsection{User Perception of Parking}

The results of the user's perception of parking respondent data from the parking area at the New Market building Bogor> $200 \mathrm{~m}$ of $42.86 \%$. Respondents chose a parking attendant capabilities for $39.53 \%$, while services provided parking attendant, $35.72 \%$ of respondents chose a less than satisfactory service.

\subsection{Results Perceptions parking attendant service}

The perception by respondents (park users) New Market parking attendant service can be seen in Bogor at Figure 3 is shown in below. 


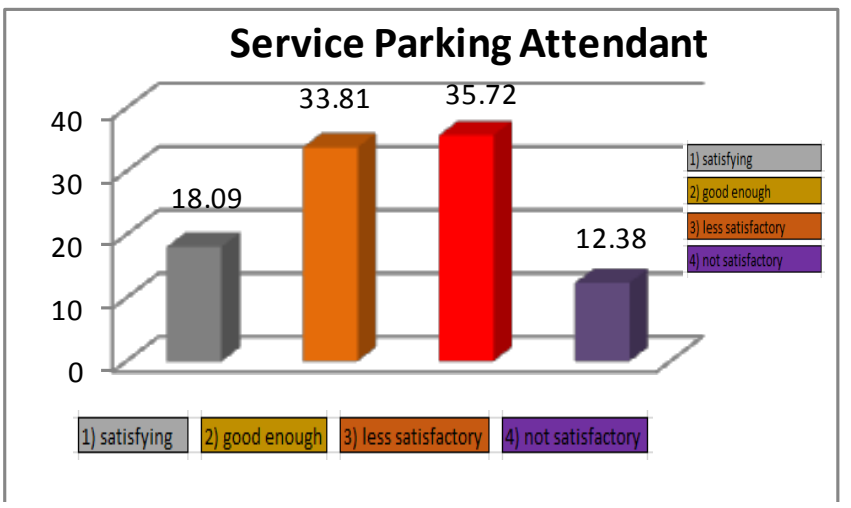

Figure 3. The results of the perception of a parking attendant service to New Market Bogor

In connection with the services provided from the parking attendant results, users who choose the less satisfactory parking $35.72 \%, 33.81 \%$ was satisfactory, satisfactory at $18,09 \%$, and $12,38 \%$ unsatisfactory. Based on these data a parking attendant service needs to be improved further in order to be better because most people said the service provided unsatisfactory parking attendant.

\subsection{Difficulty Entering the Parking Building}

Difficulty entering the building parking lot obtained from respondents can be seen below at Figure 4.

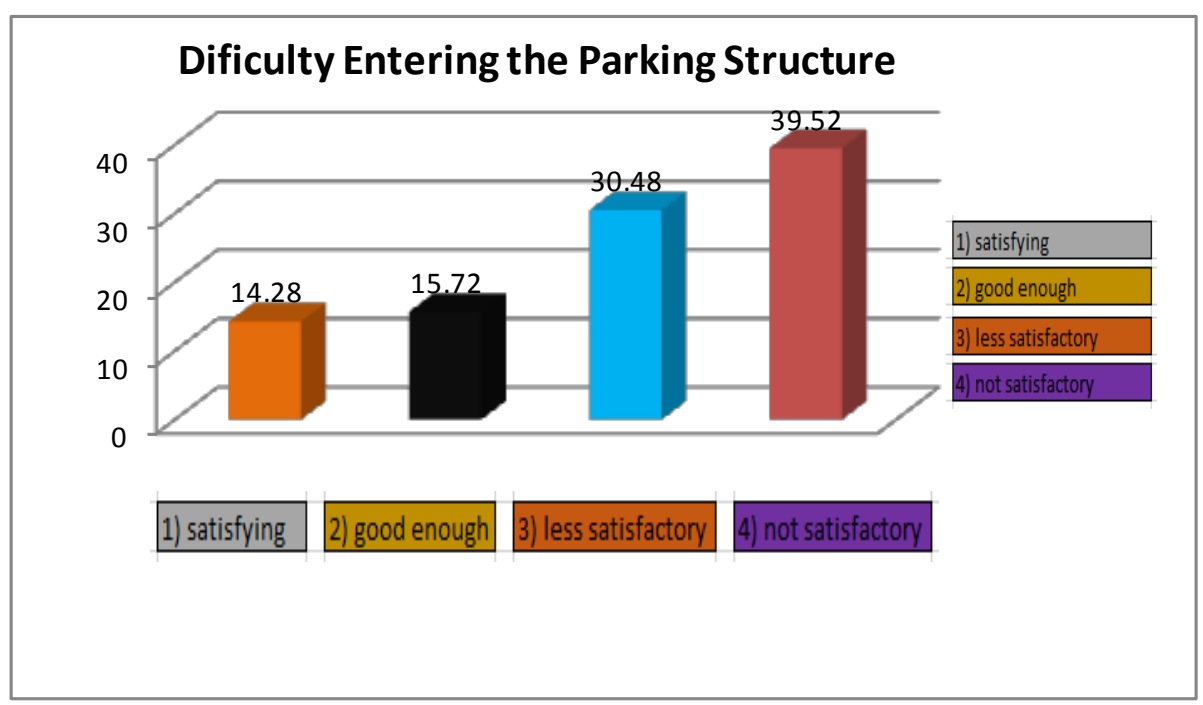

Figure 4. Difficulty entering the parking structure

Based on the results obtained from the respondents (park users) difficulty entering the parking lot of the building, respondents who chose always amounted to $39.52 \%$, and users who choose 
to park are at $30.48 \%$, while users stating parking is sometimes amounting to $15.72 \%$, and park users are choose never amounted to $14,28 \%$.

\section{CONCLUSIONS}

1) Perception assessment of park users to park a distance of $42.86 \%$ with a distance of $>200 \mathrm{~m}$, the distance is very great influence in determining the location of parking, if parking location far away from the goal, resulting users do not park their vehicles parking place specified.

2) The difficulty of entering the parking structure obtained results based on the difficulty level of $39.52 \%$. Level of difficulty occurs because the road to the parking lot is full by public transport stops place.

\section{REFERENCES}

[1]Abubakar, I., 1998, Guidelines for Planning and Operation of Parking Facilities, Jakarta, Publisher Director General of Land Transportation.

[2]Anonymous, 2011, Parking,(http://repository.usu.ac.idbitstream123456789185423 Chapter 5, 2011.pdf, 25 Agutus 2011).

[3] BAPPEDA Kota Bogor, Bogor Dalam Angka, tahun 2011.

[4]D. Setiarini, 2008. Study Winglingness To Pay. Publisher University of Indonesia, Jakarta.

[5]Fajriat, N, 2007, Parking Facilities,(http://elib.unikom.ac.id/files/disk1/139/ jbptunikompp-gdl-s1-2007-6906-nurfaj riat-chapter-ii.pdf, June 4, 2011).

[6] O. Tamin, 1998, Perencanaan dan Permodelan Transportasi, Bandung,Indonesia.

[7]Setiawan, R., 2008. Factors Affecting Ease of parking maneuvers, (Case Study Petra Christian University). National Conference on Civil Engineering (Context 2). Publisher University of Atma Jaya Yogyakarta.

[8] SYAIFUL, SYAIFUL (2005) ANALISIS KEBISINGAN ARUS LALU LINTAS DAN GEOMETRI JALAN DI KAWASAN SIMPANG LIMA KOTA SEMARANG. Masters thesis, program Pascasarjana Universitas Diponegoro. Diponegoro University, INSTITUTIONAL REPOSITORY.

[9] Syaiful, "Tingkat Kebisingan Akibat Kendaraan Bermotor Di Depan Rumah Sakit Hermina Bogor," di Seminar Nasional Teknik Sipil V 2015, Universitas Muhammadiyah Surakarta. [Online]. tanggal 19 Mei 2015. Available: https://publikasiilmiah.ums.ac.id/bitstream/handle/11617/6479/Paper Syaiful.pdf?sequ ence $=1$ \&isAllowed $=y$

[10]Widyagama, 2008. Parking, Malang, Malang Widyagama University Publishers. 